\title{
On the Informatization of University Personnel Archives
}

\author{
Rong Tang \\ Zhejiang Fashion Institute of Technology
}

\begin{abstract}
Against the background of informationization, the management mode of personnel archives tends to change from the traditional manual one to the informationization. This paper, starting from the significance of university personnel archive informatization, studies the main problems with it and, combining with the current practice, proposes an effective way out.
\end{abstract}

Keywords-universities; personnel archive management; informatization

\section{INTRODUCTION}

The informationization in the modern society, by initiating profound changes in all aspects of the society and economy, optimazing the management and utilization of information resources and improving significantly the function and efficiency of all kinds of social activities, helps to achieve a new level of the material and spiritual civilization. ${ }^{[1]}$ Therefore, against the background of informatization, the personnel archive management of universities has to join the trend, think seriously about how to reform and develop the personnel archive informationization and break through the traditional limitations of thinking, thereby to realize the transformation from traditional experience management to scientific management, an issue of the epoch the university personnel archive management is facing.

\section{THE SIGNIFICANCE}

\section{A. The Internal Need for Scientific Development of \\ Personnel Archive Management}

To enhance the construction, not only should informationization be introduced, but the transformation from the traditional management to the scientific one be realized. Replacing the traditional manual management of the entity archives with computers and network, the informationization greatly improves the efficiency of the work.

At the same time, the use of electronic carriers as storage method reduces the rates of the use of paper archives, effectively protecting the original archives and providing an effective guarantee for the sustainable development of the work.

What's more, the informationization, through automation, real-time and networking, can greatly improve the service level of the work, expand the service fields and give full play to the application value of it.

\section{B. The Need to Reform and Develop Universities}

The purpose of the Informatization of the personnel archives in universities is to explore and utilize more effectively the information resources of the archives, improve the service and utilization of the archives, realize the optimal allocation of talent resources, promote the rational flow of talents and maximize the benefit of talents. ${ }^{[2]}$ As a whole, the informatization of personnel archives is an important and integral part of the overall informatization of universities. Serving the overall strategic development of the universities asks for establishing a unified data exchange platform by promoting systematically the informatization of personnel archives and combining it with the management of administrative archives and teaching and scientific researches. This, by improving the utilization value of personnel archives, providing an efficient platform for leaders, management departments and common teachers and optimizing the overall performance of human resource management in universities, promotes the university to realize the root function of talent training, science researching and serving the society.

\section{THE PROBLEMS}

\section{A. The Lack of Management Standards}

Standardization, a basic and systematic project in informatization construction, is one of the keys to the success. Therefore, standardizing the informatization of university personnel archives is the foundation and key work in the informatization of personnel archives. Currently, most universities work hard to establish the digital archive database and develop the information management system of personnel archives. However, due to the lack of nationally overall plan and standards, the unified management standards have not been formed in the informatization which causes the randomness and casualness in the overall information construction. Some universities have only established databases, leaving alone a real network platform of management. Some others, though having basically realized the informatization of personnel archives, fails to share commonly the archive information resources since the degree of information is far from being high and the overall archive information network doesn't work smoothly.

\section{B. The Lowness of Comprehensive Quality and Expertise of the Managers}

The designers, implementers and users of information products, archive management personnel act as the links and 
bridges between archive information resources and end-users. However, a big gap exists between the overall low quality and expertise of the archive managers together with the many problems with the team construction of talents and the needs of the development of informatization.

Relevant statistics show that, among the comprehensive archive management staff at all levels, the proportion of those with good education is low and that the proportion of the undergraduates and above is less than $35 \%$ and that of the undergraduate personnel majoring in archives is less than $20 \%$. ${ }^{[3]}$ Similarly, the overall quality of the management staff of university archives is currently not high and universities lack the professional management talents of high quality, especially the complex talents expert in both the management of personnel archives and the skills of information operation. At the same time, the current slighting both of the supplement of new personnel and the professional development of the present managers in the university human resource management restricts seriously the development of the construction of informatization of archive personnel in universities.

\section{The Backwardness of the Management System}

At present, the archives management system in universities is basically of a traditional mode. Archives are stored and managed in different departments, such as organization departments, personnel departments, teaching administration departments, students' affair departments and even different schools of the universities. In the process of promoting the work, most universities fail to set up unified agencies for the work. Lacking of coordination, a standardized and scientified management is difficult to reach. All relative departments choose their own modes which renders difficult the resource sharing among different institutions and departments. At the same time, the serious data construction and repeated investment in infrastructure inspires a waste of manpower, goods and money.

\section{THE WAYs OUT}

\section{A. Improving the Management Mechanism}

To promote the work requires to improve the management mechanism. The mode of "centralized, unified and hierarchical responsibility" can be adopted so as to strengthen the overall planning and the construction of rules and regulations. First of all, the work process should be unified, the work network established and the departments and persons in charge made certain. So that, contradictions and problems can be dealt with as soon as they appear. ${ }^{[4]}$ Secondly, all the existing systems should be systematically arranged and improved, and the missing rules and regulations established, so that there are rules to be followed. Further on these foundations, a unified management organization of the work should be established to coordinate the investment of infrastructure, supervise the execution of duties, formulating reasonable incentive policies and so on. So that, the development of the work can be orderly promoted.

\section{B. Strengthening the Team Construction}

To promote the work, the guarantee of a high-quality team is needed. It is necessary to improve the overall quality of the personnel by continuously improving the mechanism of selecting, training, flowing, encouraging and securing the personnel.

Firstly, a scientific and stable selection mechanism should be established and the full-time personnel staffed sufficiently in accordance with the existing state regulations. At the same time, effective measures should be taken to enrich the reserve personnel.

Secondly, the pre job training and the continuing on-the-job training should be improved. As a highly professional work, archive management requires good political quality and professional ethics. Therefore, a personnel archive manager, before they begin the work, must accept the strict and systematic pre job training and obtain the qualification certificate issued by the archive department and the organization and personnel department. At the same time, with the transformation of the archive work from the traditional manual mode to the informatized one, the personnel archive managers have to meet the updated work standards and requirements, especially those of the modern information technolgy. Universities should, through broadening the training mode and continuing on-the-job training, make complex talents out of personnel archive managers who are familiar with business and master information technology.

Thirdly, the system of assessment and incentive remains to be established. A smooth job rotation system, a performance appraisal system and a title promotion system can be established to create space for the personnel's development and encourage their work vitality.

\section{Standardizing the Work}

Standardization is the most important basis of the work since informatizing it is a systematic and complex work which involves many departments and persons and the key to success lies largely on the integrity of the construction of the electronic archives system.

First of all, a unified management standard covering planning, standards and norms is needed. Under this unified standard, the arrangement, preservation, forwarding and use of electronic data can keep order and the phenomena of incompatibility, acting only on one's own free will and repeated construction be avoided.

Secondly, the construction of technical standard system should be carried out. The system should consist of basic hardware construction standards, database construction standards, and software development standards. ${ }^{[5]}$ In addition, in the process of promoting the informatization of university personnel archives, we should strictly abide by the relevant standards and specifications of the state, trying to use standardized information management software. 


\section{CONCLUSION}

The informatization construction of personnel archives management in universities is not only the inevitable trend of the development of society and the era, but also the inherent demand of the reform and development of universities themselves. The transformation of personnel archives from traditional manual management to information management, a complex system project which needs multi-disciplinary knowledge and multi-department cooperation, is a long-term and gradual process and needs to be developed and perfected in practice. In addition to what are mentioned above, we, in the development of information management of personnel archives, should learn from foreign countries their advanced ideas and successful experiences.

At the same time, universities, a subsystem of the society, should work with other social forces to promote the research on the legal construction of the personnel archive system of our country and make greater contributions in the talent training, scientific research and serving the society.

\section{REFERENCES}

[1] https://baike.so.com/doc/2621395-2767929.html

[2] Lin Hua Ye. Principles and key issues of information construction of personnel archives in Colleges and universities. Scientific and technological information development and economy [J], Vol. eighteenth, volume twenty-first, 2008

[3] Chen Ruizhu. Thoughts on strengthening the construction of personnel archives management team in Colleges and universities [J]. Journal of Harbin Vocational and Technical College, 2014 issue fourth

[4] Wang Yan. Research on information management of personnel archives in higher vocational colleges. Take Ji'nan vocational colleges as an example [D]. Master's degree of Shandong University, 2014, P36.

[5] Ma Lin. Research on the construction of information management mode of cadre archives [D]. Master's thesis of Dalian University of Technology, 2017, P32. 